\title{
Estimating the economic burden attributable to some risk factor
}

\author{
FéFernández Hernández* and Efraín Sánchez González \\ Department of Medical Science, University of medical Science of Havana, Cuba
}

\begin{abstract}
Introduction: The precise estimation about the economic burden attributable to some risk factor constitutes an objective necessity from the economic research for the Public Health. The precision estimating the economic burden attributable to some risk factor is determined by the inclusion of the definer characteristics for the risk factor. By this way the estimated economic burden will show in details the economic impact from the risk factor over the researched population.

Objective: To characterize the estimation of the economic burden attributable to some risk factor.

Materials and methods: were made a descriptive research about the economic burden attributable to the risk factor. Were utilized the inductive-deductive, the analysis and synthesis and the comparative like theorical methods. Like empiric method was utilized the bibliographic research.

Results: The economic burden attributable to the risk factor is determined by the happening of three main independent successes: the existence of some person affected by the risk factor, the existence of the morbidity related with the researched risk factor and the effective demand attributable to the risk factor. Conclusions: Estimating the economic burden to the risk factor is necessary to difference between the potential demand and the effective demand of health services. Also, the determination of the morbidity attributable to the risk factor must be in correspondence with the specific particularities which determines the researched risk factor.
\end{abstract}

\section{Introduction}

The estimation of the economic burden attributable to some risk factor is very important measuring the economic impact from the risk factor over the researched population. At same time this rate is taken as reference applying public policies in the control of the cited risk factor $[1,2]$.

The precise estimation of the economic burden attributable to some risk factor constitutes an objective necessity from the economic research for the Public Health. This importance becomes stronger when the socioeconomic subject plays a main role for the risk factor control $[3,4]$.

Each risk factor is exclusive and particular in its own essence with own characteristic that identify it. Then, the precision estimating the economic burden in the cited risk factor is determined by the appropriate inclusion of these characteristics in the estimation process. By this way the estimated economic burden will show in detail the whole economic impact from the risk factor over the researched population $[5,6]$.

\section{Objective}

To characterize the estimation of the economic burden attributable to some risk factor.

\section{Materials and methods}

Was made a descriptive research about the economic burden attributable to the risk factor. Were utilized the inductive-deductive, the analysis and synthesis and the comparative like theoretical method. Like empiric method was utilized the bibliographic research.

\section{Results}

Usually is utilized the following formula estimating the sickness cost's or the cost attributable to some risk factor [7].

$\mathrm{SC}=$ sickness burden ${ }^{\star}$ economic amount

Where SC: sickness cost.

At same time the sickness burden is calculated like:

$\mathrm{SB}=\mathrm{AF}^{*} \mathrm{MP}^{7}$

Where SB: sickness burden

$$
\begin{aligned}
& \text { AF: attributable fraction } \\
& \text { MP: morbidity probability's }
\end{aligned}
$$

The attributable fraction is calculated like show the following equation:

\section{$\mathrm{AF}=\mathrm{Nx} / \mathrm{N}^{7}$}

Where Nx: population exposed to the risk factor $\mathrm{N}$ : whole researched population.

${ }^{*}$ Correspondence to: FéFernández Hernández, Department of Medical Science, University of medical Science of Havana, Cuba, E-mail: fefh@infomed.sld.cu

Key words: risk factor, economic burden, effective demand

Received: August 21, 2018; Accepted: August 28, 2018; Published: September 03, 2018 
Finally, the sickness burden can be calculated like:

\section{$\mathrm{SB}=\mathrm{Nx} / \mathrm{N}^{\star} \mathrm{MP}$}

The rate $\mathrm{Nx} / \mathrm{N}$ is equivalent to the probability to have some person exposed to the risk factor. Then, the sickness burden related with some risk factor can be expressed like:

\section{$\mathrm{SC}=\mathrm{PNX}{ }^{\star} \mathrm{MP}$}

Where PNX: probability to have some person exposed to the risk factor in the researched population.

Then, the formulation estimating the cost attributable to some risk factor can be written like:

\section{$\mathrm{RFC}=\mathrm{PNX}^{\star} \mathrm{MP}^{\star}$ economic amount}

Where RFC: cost attributable to the risk factor researched

Applying this formula estimating the costs attributable to some risk factor it overvalues the true costs attributable to the researched risk factor. This is because this formula application means that the single existence of the risk factor carries to Public Health costs' attributable to the researched risk factor $[8,9]$.

Not all people affected by some risk factor carry to health spends attributable to the researched risk factor. Only the persons affected by the risk factor that cause an effective demand of health service purely attributable to the cited risk factor carry to the cited cost $[10,11]$.

The economic burden attributable to some risk factor like similar of the risk factor cost's is determined by the happening of three successes at same time:

1. The existence of the person exposed to the risk factor

2. The existence of the morbidity significantly related with the risk factor

3. The existence of the effective demand of health services purely attributable to the risk factor $[12,13]$.

If some element isn't present the economic burden attributable to the risk factor should be null because the economic burden attributable to the risk factor should exist only if these three elements are present at same time.

Every one of these successes has associated a probability of existence. Given the condition of these successes of be independent between them, according to the Theorem of the Multiplication, the probability of the economic burden attributable to the risk factor will be equal to the multiplication of the probability associated to each success that determine the economic burden [14].

A similar analysis was made by authors in other research. This analysis was focused in the smoking economic burden showing the difference between the epidemiologic burden and the economic burden and the difference between potential demand and effective demand of health services attributable to the risk factor [9].

In all case of risk factor research about economic burden is important to define the limit of the effective demand inside the potential demand of health services attributable to the researched risk factor. Thus, is possible obtain a better estimation of the economic burden attributable to some risk factor.

\section{Conclusions}

Estimating the economic burden attributable to some risk factor is necessary to limit the effective demand from the potential demand of health services attributable purely to the researched risk factor. This delimitation must be in correspondence to the particular's characteristics of the cited risk factor.

\section{References}

1. Fabelo Roche J, Lorenzo Vázquez EL, Iglesias Moré S, Álvarez-Martínez E (2019) Impact of health warnings on cigarette packs on Cuban smokers. Health \& Society 9: 306-313.

2. González Menéndez R (2017) Tácticas para vencer las drogas blandas y duras. Consejos de un viejo adictólogo. Santiago de Cuba: Editorial Oriente.

3. Fernández Hernández F, Sánchez González E (2019) La carga económica de tabaquismo. España: Editorial Académica Española.

4. Fernández Hernández F, Sánchez González E (2018) Algorithm to calculate the smoking economical burden in active and passive smokers. MOJ Toxicol 4: 373-375.

5. Sánchez Herrera, Beatriz (2016) Concept load on theoretical models on chronic disease: systematic review. Rev public health 18: 976-985.

6. Sánchez Fernández NE, Sánchez Clemente A, Torres Félix L, Valiente Matos LM Thomas Ferrer F (2018) Importance of cost awareness for the Integral General Stomatologist. Rev Inf Cient 97: 298-306.

7. Toledo Curbelo GJ (2008) Fundamentos de Salud Pública. Segunda edición. La Habana: Ciencias Médicas, Pág 184-186.

8. Seuc Armando H, Domínguez Emma (2005) About the calculation of disease burden due to morbidity. Rev Cubana Hig Epidemiol p. 43.

9. Fernández HF, Sánchez GE (2017) Epidemiological burden vs. economic burden of smoking due to morbidity. Rev Ciencias Médicas 21: 60-66.

10. Fernández HF, Sánchez GE (2019) Economic Inequity Attributable to Smoking Ratio's for the Public Health. Health Econ Outcome Res Open Access 4: 161.

11. Fernández HF, Sánchez GE (2019) The socioeconomic inequity attributable to smoking. J Med Pract and Rev 3: 559-562.

12. Landrove Rodríguez O, Morejón-Giraldoni A, Venero-Fernández S, Suárez-Medina R, Almaguer-López M, et al. (2018) Enfermedades no transmisibles: factores de riesgo y acciones para su prevención y control en Cuba. Rev Panam Salud Publica 42: e23.

13. Ciria Martín A, Capote Rodríguez A, Sardiñas Aguirre SY, García Milian AJ (2016) Los procesos sociales y medioambientales en la salud de niños asmáticos: desafíos para la ciencia y la tecnología en Cuba. Rev Cubana Med Gen Integr p. 32.

14. Mateos G, Morales A (2002) Historia de la Probabilidad (desde sus orígenes hasta Laplace) y su relación con la historia de la teoría de decisión. Historia de la Probabilidad y Estadística (AHEPE) AC, Madrid.

Copyright: (2019 Hernández F. This is an open-access article distributed under the terms of the Creative Commons Attribution License, which permits unrestricted use, distribution, and reproduction in any medium, provided the original author and source are credited. 